\title{
Distal 18q Deletion Syndrome
}

National Cancer Institute

\section{Source}

National Cancer Institute. Distal 189 Deletion Syndrome. NCI Thesaurus. Code C130986.

A contiguous gene deletion syndrome involving deletion of the distal portion of the long arm of chromosome 18. The clinically heterogenous condition is characterized by some or all of the following: growth hormone deficiency with resulting short stature; hand, foot, skull, facial, and genital anomalies; hypotonia; and developmental delay. 